\title{
Water Quality Assessment of Valapattanam River Basin in Kerala, India, using Macro-Invertebrates as Biological Indicators
}

\author{
Puthenveedu Sadasivan Pillai Harikumar ${ }^{*}$, Radhakrishnan Deepak and Ayarkode Ramachandran \\ Sabitha
}

Water Quality Division, Centre for Water Resources development and Management, Kunnamangalam, Kozhikode673571, Kerala, India

\begin{abstract}
Biomonitoring is a valuable assessment tool that is receiving increased use in water quality monitoring programs of all types. The study was to identify the freshwater Benthic Macro-invertebrates and to find out the biological water quality using BWQC developed by Central Pollution Control Board (New Delhi) in Valapattanam River, Kerala originating from Brahmagiri of Western Ghats. A total of 408 individuals belonging to 20 genera and 14 families were collected from the five stations of the River Valapattanam during pre-monsoon, monsoon and post-monsoon periods. Chironomus sps a pollution tolerant species were present in most of the stations showing high degree of organic pollution. The downstream stations showed moderate pollution during pre and post monsoon seasons and slight improvement during monsoon. The water quality of the Valapattanam River was deteriorated by sewage effluents and agricultural activities, diminishing the abundance of aquatic insects and macro-invertebrates.
\end{abstract}

Keywords: Benthic Macro-invertebrates, Biological indicators, Biological monitoring, Biological Water Quality Criteria (BWQC), Pollution.

\section{INTRODUCTION}

River water pollution is a major global problem. Biological indicators are species used to monitor the health of an environment or ecosystem. A biological approach to water quality monitoring incorporates the use of stream organisms themselves as a basis for pollution detection. Biological monitoring or bio monitoring, is the use of biological response to assess changes in the environment, generally changes due to anthropogenic causes [1]. Bio monitoring programs may be qualitative, semi quantitative or quantitative. Bio-monitoring is a valuable assessment tool that is receiving increased use in water quality monitoring programs of all type [2]. Benthic macro- invertebrates are the most popular and commonly used group of fresh water organisms in assessing water quality [3]. Benthic macro invertebrates have a sedentary and long life span, sensitive community response to organic loading, thermal impacts, substrate alteration and toxic pollution [4]. They are regarded as the most informative bio indicators of water pollution. Macro invertebrates and water quality are interrelated to each other, as macro invertebrates are a potential indicator of water quality [5]. They are most frequently used in bio monitoring studies because the responses of macro invertebrates to organic and inorganic pollution have been extensively documented [6,7]. They have sensitive life stages that

\footnotetext{
*Address correspondence to this author at the Scientist and Head Water Quality Division, Centre for Water Resources development and Management, Kunnamangalam, Kozhikode-673571, Kerala, India;

Tel: 919847781444; E-mail: drpshari@yahoo.co.in
}

respond to stress and integrate effects of both short-term and long-term environmental stressors [8] and that they are important areas for maintaining biodiversity [9, 10]. The benthic macro invertebrate population may vary in time and space and their diversity within a certain area are clearly related to fertility and productivity of overlying water [11].

The Kerala State is blessed with 44 Rivers, however many of these are under threat due to anthropological activities like encroachment, sand mining, degradation of river banks, construction of bunds across the rivers and pollution. According to the report on "Environmental monitoring programme on water quality, 2012" by Kerala State council for Science, Technology and Environment, most of the rivers in Kerala shows evidences of organic pollution and biota is facing stress because of this [12]. Valapattanam River is the largest River in the Kannur District. It originates from the Brahmagiri of Western Ghats of Kodagu and discharge to the Arabian Sea, near Azheekal. The length of main stream is $110 \mathrm{~km}$. Srikandapuram, Valiyapuzha, Venipuzha and Aralampuzha are the main Tributaries of Valapattanam River. Valapattanam River is well known for its wood-based industries. Valapattanam is also a famous fishing harbour as well as the main source of the irrigation project (Pazhassi Dam) in the district. Considerable number of human population depends on this river for their daily livelihood. A total of 5 sampling stations (Fig. 1) were selected for the biological analysis during three different seasons ie pre monsoon (February- May), monsoon (June -September) and post monsoon (October - January) seasons. The major objective of the study was to identify and use fresh water Benthic Macroinvertebrates in Valapattanam River to assess the biological 


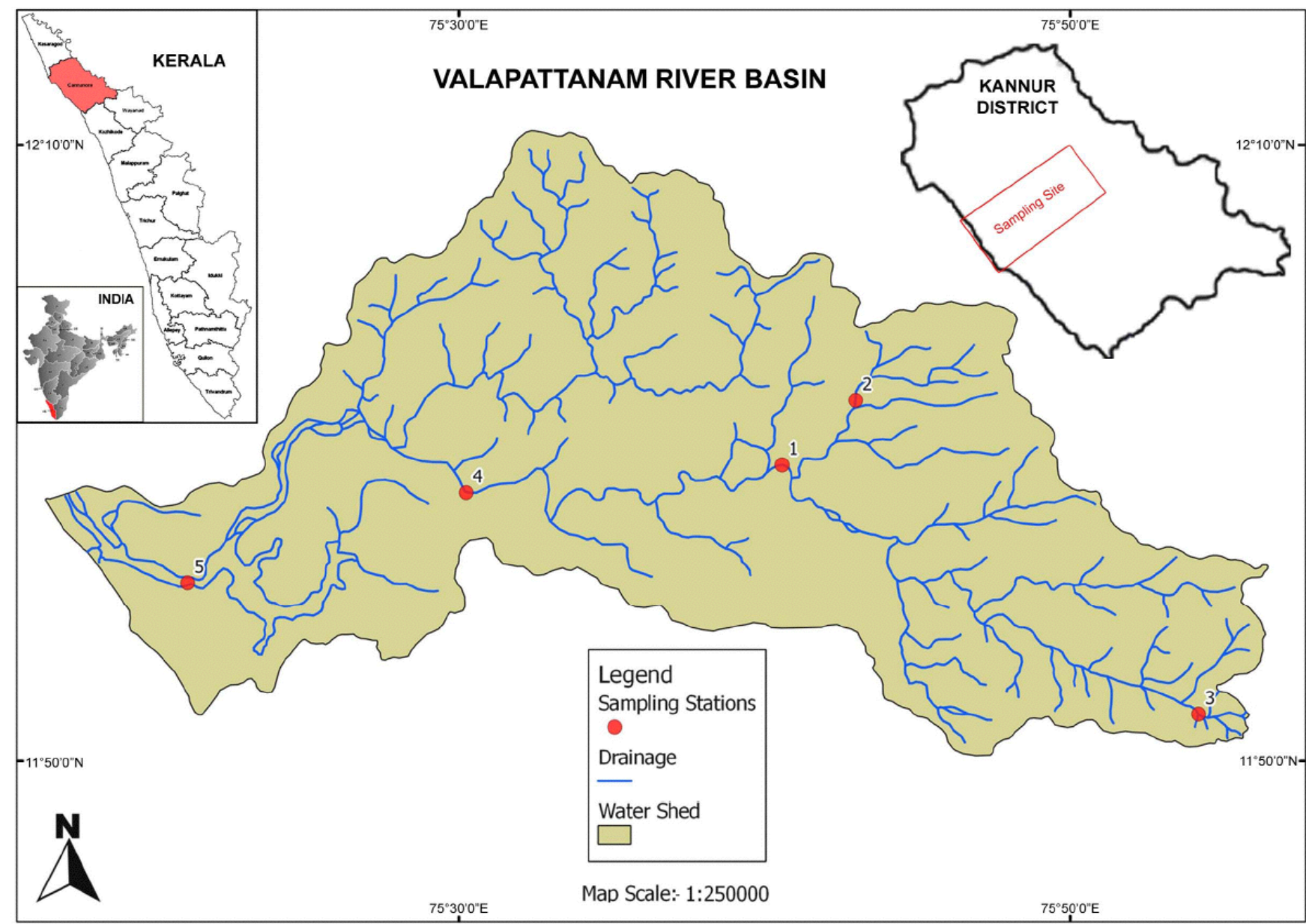

Fig. (1). Map of Valapatanam River basin showing the sampling locations.

water quality using BWQC developed by Central Pollution Control Board (New Delhi).

\section{MATERIALS AND METHODS}

Sediment samples were collected from Valapattanam River basin during three seasons (pre-monsoon, Monsoon and post-monsoon) using standard procedure prescribed by Central pollution Control Board (CPCB, 1999) [13]. The detail of the sampling stations is given in Table 1. Sediment samples were collected with Ekman dredge and benthic macro-invertebrates was soon filtered through the sieves of mesh size $0.5 \mathrm{~mm}$ and $0.2 \mathrm{~mm}$ and preserved in $5 \%$ formaldehyde, sorted and identified using standard keys $[14,15]$.

To assess the actual health of water bodies, Central pollution Control Board (CPCB, (1999) has derived a Biological Water Quality Criteria (BWQC) for water quality evaluation (Table 2). This system is based on the range of saprobic values and diversity of the benthic macro-invertebrate families with respect to water quality. Saprobic score method involves a quantitative inventory of the presence of MacroInvertebrate benthic fauna up to family level of taxonomic precision. All possible families having saprobic indicator value are classified on a score scale of 1 to 10 according to the preference for saprobic water quality. The saprobic scores of all the families are to produce Bio-Monitoring Working Party (BMWP) index. The families which are more sensitive to pollution have been assigned scores of 10 while the most pollution tolerant families have been assigned scores of 1 and 2 .

Abundance scale:

$\mathrm{A}=$ single (one individual)

$\mathrm{B}=$ scarce (2-10 individuals)

$\mathrm{C}=$ common (10-50 individuals)

$\mathrm{D}=$ abundant (50-100 individuals)

$\mathrm{E}=$ excessive (more than 100 individuals or only one species)

The diversity score is the ratio of the total number of different animals (runs) and the total number of organisms encountered. The ratio of diversity has a value between 0 and 1. Diversity score method involves a pair-wise comparison of sequentially encountered individuals, and the differences of two specimens can easily be observed up to species level, no taxonomic skill is required. First observed animal is always different and scored as 1 run. When the next observed is different from the last, a new run starts. The encounter of an individual which cannot be discerned from the last does not increment the number of runs.

Saprobic score $=$ Grand total multiplied score $/$ Grand total number of families encountered 
Table 1. Details of sampling locations along the river course.

\begin{tabular}{|c|c|c|c|c|}
\hline $\begin{array}{c}\text { Sampling } \\
\text { Code }\end{array}$ & Sampling Station & Latitude & Longitude & Details \\
\hline \hline 1 & Aralam bridge & $11^{\circ} 59.637^{\prime}$ & $75^{\circ} 40.589^{\prime}$ & Mixed vegetation \\
\hline 2 & Vallithode Bridge & $12^{\circ} 01.736^{\prime}$ & $75^{\circ} 42.990^{\prime}$, & $\begin{array}{c}\text { Mixing point Kundurpuzha with the river the } \\
\text { river from Koottupuzha. }\end{array}$ \\
\hline 3 & Near Kottiyoor Temple & $11^{\circ} 52.422^{\prime}$ & $75^{\circ} 59.974^{\prime}$, & $\begin{array}{c}\text { One side of the river is forest, highly faecal } \\
\text { contaminated. }\end{array}$ \\
\hline 5 & Munambukadavu bridge & $11^{\circ} 58.737^{\prime}$ & $75^{\circ} 30.278^{\prime}$ & $\begin{array}{c}\text { Mixing point of Sreekandapuram river with the } \\
\text { main stream, Plantation area. }\end{array}$ \\
\hline 5 & Valapattanam Bridge & $11^{\circ} 55.802^{\prime}$ & $75^{\circ} 21.183^{\prime}$ & $\begin{array}{c}\text { Dense Mangrove Vegetation. Township area, } \\
\text { industries and wood factories near the shore. }\end{array}$ \\
\hline
\end{tabular}

Table 2. Biological Water Quality Criteria (BWQC).

\begin{tabular}{|c|c|c|c|c|c|}
\hline SI No & Range of Saprobic Score & Range of Diversity Score & Water Quality & Water Quality Class & Indicator Colour \\
\hline \hline 1 & 7 and more & $0.2-1.0$ & Clean & A & Blue \\
\hline 2 & $6-7$ & $0.5-1.0$ & Slight Pollution & L & Gight Blue \\
\hline 3 & $3-6$ & $0.3-0.9$ & Moderate Pollution & D \\
\hline 4 & $2-5$ & $0.4-l e s s$ & Heavy Pollution & Orange \\
\hline 5 & $0-2$ & $0-0.2$ & Severe Pollution & Red \\
\hline
\end{tabular}

Diversity score $=$ Number of runs $/$ Number of organisms

To indicate changes in water quality to different grades of pollution level, the entire taxonomic groups with their range of saprobic score from 1 to 10 , in combination with the range of diversity score from 0 to 1 has been classified into five different classes of water quality. The abnormal combination of saprobic score and diversity score indicates sudden change in environment conditions.

\section{RESULTS}

The benthic community which was identified during three seasons is shown in Table $\mathbf{3}$.

A total of 408 individuals belonging to 20 genera and 14 families were collected from the five stations of the River Valapattanam during pre monsoon, monsoon and post monsoon periods. The highest diversity of benthic macro- invertebrates was noticed in the station near Aralam Bridge and the lowest diversity was reported in the downstream station during pre monsoon season. Macro invertebrates belonging to orders Tricoptera, Diptera, Ephemeroptera, Odonata, Coleoptera, Hemiptera, Neotaenioglossa and Hygrophila were encountered. During the present study, Ephemeroptera was the most diverse with families Leptophlebiidae, Ephemerellidae, Baetidae, and Heptageniidae. Tricoptera, Diptera and Coleoptera had two families each. One family each from the other orders Odonata, Hemiptera. Neotaenioglossa, Hygrophila were also observed. The most dominant genera of
Ephemeroptera were Megaglena and Baetes. For Diptera Chironomus were the only representatives. Tricoptera genera were dominated by Potamya and Hydropsychae. Coleoptera was dominated by Dryops larvae and Odonata by Paragomphus. The presence of Baetis, (Ephemeroptera), Paragomphus (Odonata), Macrostemum, Hydropsychae, (Tricoptera) and Dryops (Coleoptera) were quite predominant, since many species of Ephemeroptera, Odonata, Tricoptera and Coleoptera show morphological and/or behavioral adaptation for attachment to surfaces of stones or other substrates between short bursts of swimming [16].

Biological Water Quality Criteria (BWQC), based on the range of saprobic and diversity values of the benthic macro invertebrate families were displayed for the five sampling stations is in Table 4. At Aralam Bridge the river water quality decreased from pre monsoon to post monsoon. Here saprobic score and diversity score had negative correlation (-0.99). While Vallithode Bridge showed a lower saprobic value during pre monsoon, when compared to the value obtained during monsoon and post monsoon. Diversity score was also higher during the pre monsoon (0.60), with respect to monsoon $(0.50)$. The scores were in negative correlation $(-0.60)$ here as well but water quality was improved from pre monsoon to post monsoon. Remaining three downstream stations showed similar trend in water quality i.e. only slight improvement during monsoon and back to same condition at post monsoon which may be due to a higher flow rate and flooding nature of the river during monsoon. Saprobic scores 
Table 3. Benthic community identified in Valapattanam River Basin.

\begin{tabular}{|c|c|c|c|c|}
\hline Phylum & Class & Order & Family & Genus \\
\hline \multirow{17}{*}{ Arthropoda } & \multirow{17}{*}{ Insecta } & \multirow{6}{*}{ Tricoptera } & Rhyachophilidae & Himalopsyche sps \\
\hline & & & \multirow{5}{*}{ Hydropsychidae } & Potamya sps \\
\hline & & & & Cheumatopsyche sps \\
\hline & & & & Polymorphan sps \\
\hline & & & & Macrostemum sps \\
\hline & & & & Hydropsychae sps \\
\hline & & Diptera & Chironomidae & Chironomus larvae \\
\hline & & \multirow{5}{*}{ Ephemeroptera } & \multirow{2}{*}{ Leptophlebiidae } & Habrophlebiodes sps \\
\hline & & & & Megaglena sps \\
\hline & & & Ephemerellidae & Ephemerella sps \\
\hline & & & Baetidae & Baetis sps \\
\hline & & & Heptageniidae & Epeorus sps \\
\hline & & \multirow{2}{*}{ Odonata } & \multirow{2}{*}{ Gomphidae } & Paragomphus sps \\
\hline & & & & Leptogomphus sps \\
\hline & & \multirow{2}{*}{ Coleoptera } & Dryopidae & Dryops larvae \\
\hline & & & Psephenidae & Psephenoidinae sps \\
\hline & & Hemiptera & Belastomatidae & Sphaerodema sps \\
\hline \multirow{2}{*}{ Mollusca } & \multirow{2}{*}{ Gastropoda } & Neotaenioglossa & Thiaridae & Melanoides sps \\
\hline & & Hygrophila & Lymnaeidae & Lymnaea sps \\
\hline
\end{tabular}

Table 4. Biological water quality of Valapattanam River during pre monsoon, monsoon and post monsoon seasons.

\begin{tabular}{|c|c|c|c|c|c|}
\hline Name of the Stations & Season & Saprobic Score & Diversity Score & Water Quality & Water Quality Class \\
\hline \multirow{3}{*}{ Aralam bridge } & Pre monsoon & 7.00 & 0.39 & Clean & A \\
\hline & Monsoon & 6.15 & 0.51 & Slight pollution & B \\
\hline & Post monsoon & 6.15 & 0.50 & Slight pollution & $\mathrm{B}$ \\
\hline \multirow{3}{*}{ Vallithode Bridge } & Pre monsoon & 3.00 & 0.60 & Moderate pollution & $\mathrm{C}$ \\
\hline & Monsoon & 6.56 & 0.50 & Slight pollution & B \\
\hline & Post monsoon & 6.89 & 0.58 & Slight pollution & B \\
\hline \multirow{3}{*}{ Near Kottiyoor Temple } & Pre monsoon & 5.00 & 0.43 & Moderate pollution & $\mathrm{C}$ \\
\hline & Monsoon & 6.20 & 0.75 & Slight pollution & B \\
\hline & Post monsoon & 6.00 & 0.47 & Moderate pollution & $\mathrm{C}$ \\
\hline \multirow{3}{*}{ Munambukadavu bridge } & Pre monsoon & 5.38 & 0.35 & Moderate pollution & $\mathrm{C}$ \\
\hline & Monsoon & 6.11 & 0.72 & Slight pollution & B \\
\hline & Post monsoon & 5.56 & 0.33 & Moderate pollution & $\mathrm{C}$ \\
\hline \multirow{3}{*}{ Valapattaanam Bridge } & Pre monsoon & 5.70 & 0.30 & Moderate pollution & $\mathrm{C}$ \\
\hline & Monsoon & 6.00 & 0.67 & Slight pollution & B \\
\hline & Post monsoon & 5.91 & 0.41 & Moderate pollution & $\mathrm{C}$ \\
\hline
\end{tabular}


Table 5. Abundance of benthic macro invertebrates.

\begin{tabular}{|c|c|c|c|c|c|c|c|c|}
\hline \multirow{2}{*}{ Stations } & \multirow{2}{*}{ Family } & \multirow{2}{*}{ Genus Name } & \multicolumn{2}{|c|}{ Pre } & \multicolumn{2}{|c|}{ Mon } & \multicolumn{2}{|c|}{ Post } \\
\hline & & & $\mathbf{N}$ & $\mathbf{A}$ & $\mathbf{N}$ & $\mathbf{A}$ & $\mathbf{N}$ & $\mathbf{A}$ \\
\hline \multirow{19}{*}{ Aralam Bridge } & Rhyachophilidae & Himalopsyche sps & 5 & $\mathrm{~B}$ & 2 & B & 1 & A \\
\hline & \multirow{5}{*}{ Hydropsychidae } & Potamya sps & 8 & B & 1 & A & 1 & A \\
\hline & & Cheumatopsyche sps & 1 & A & 2 & $\mathrm{~B}$ & 2 & B \\
\hline & & Polymorphan sps & 1 & A & 1 & A & 3 & B \\
\hline & & Macrostemum sps & 1 & A & 2 & $\mathrm{~B}$ & 3 & B \\
\hline & & Hydropsychae sps & 4 & B & 1 & A & 4 & B \\
\hline & Chironomidae & Chironomus larvae & - & - & 1 & A & 3 & $\mathrm{~B}$ \\
\hline & \multirow{2}{*}{ Leptophlebiidae } & Habrophlebiodes sps & 1 & $\mathrm{~A}$ & 3 & B & 1 & A \\
\hline & & Megaglena sps & - & - & 4 & B & 1 & A \\
\hline & Ephemerellidae & Ephemerella sps & - & - & 2 & $\mathrm{~B}$ & 1 & A \\
\hline & Baetidae & Baetis sps & - & - & 3 & B & 1 & A \\
\hline & Heptageniidae & Epeorus sps & 1 & A & 1 & A & 1 & A \\
\hline & \multirow{2}{*}{ Gomphidae } & Paragomphus sps & - & - & 2 & B & 3 & B \\
\hline & & Leptogomphus sps & - & - & 3 & $\mathrm{~B}$ & 3 & B \\
\hline & Dryopidae & Dryops larvae & - & - & 2 & $\mathrm{~B}$ & 3 & B \\
\hline & Psephenidae & Psephenoidinae sps & - & - & 2 & $\mathrm{~B}$ & 2 & B \\
\hline & Thiaridae & Melanoides sps & - & - & 2 & $\mathrm{~B}$ & 2 & $\mathrm{~B}$ \\
\hline & Lymnaeidae & Lymnaea sps & 1 & A & 1 & A & 1 & A \\
\hline & Belastomatidae & Sphaerodema sps & - & - & 2 & $\mathrm{~B}$ & 2 & $\mathrm{~B}$ \\
\hline \multirow{14}{*}{ Vallithode Bridge } & Rhyachophilidae & Himalopsyche sps & - & - & 8 & B & 1 & A \\
\hline & \multirow{5}{*}{ Hydropsychidae } & Potamya sps & 4 & $\mathrm{~B}$ & 1 & A & 4 & B \\
\hline & & Cheumatopsyche sps & - & - & 1 & A & 1 & A \\
\hline & & Polymorphan sps & - & - & 2 & $\mathrm{~B}$ & 1 & A \\
\hline & & Macrostemum sps & - & - & 1 & A & 1 & A \\
\hline & & Hydropsychae sps & 2 & $\mathrm{~B}$ & 2 & B & 2 & B \\
\hline & Chironomidae & Chironomus larvae & - & - & 2 & B & - & - \\
\hline & \multirow{2}{*}{ Leptophlebiidae } & Habrophlebiodes sps & 1 & A & 2 & $\mathrm{~B}$ & 1 & A \\
\hline & & Megaglena sps & 1 & A & 1 & A & 1 & A \\
\hline & Ephemerellidae & Ephemerella sps & - & - & 1 & A & 2 & B \\
\hline & Baetidae & Baetis sps & 1 & A & 2 & B & 1 & A \\
\hline & Heptageniidae & Epeorus sps & - & - & 2 & B & 5 & B \\
\hline & \multirow{2}{*}{ Gomphidae } & Paragomphus sps & - & - & 2 & $\mathrm{~B}$ & 2 & B \\
\hline & & Leptogomphus sps & - & - & - & - & - & - \\
\hline
\end{tabular}


Table 5. contd...

\begin{tabular}{|c|c|c|c|c|c|c|c|c|}
\hline \multirow{2}{*}{ Stations } & \multirow{2}{*}{ Family } & \multirow{2}{*}{ Genus Name } & \multicolumn{2}{|c|}{ Pre } & \multicolumn{2}{|c|}{ Mon } & \multicolumn{2}{|c|}{ Post } \\
\hline & & & $\mathbf{N}$ & $\mathbf{A}$ & $\mathbf{N}$ & $\mathbf{A}$ & $\mathbf{N}$ & $\mathbf{A}$ \\
\hline & Dryopidae & Dryops larvae & - & - & - & - & 1 & A \\
\hline & Psephenidae & Psephenoidinae sps & - & - & - & - & - & - \\
\hline & Thiaridae & Melanoides sps & - & - & - & - & - & - \\
\hline & Lymnaeidae & Lymnaea sps & 1 & A & 1 & A & 1 & A \\
\hline & Belastomatidae & Sphaerodema sps & - & - & - & - & - & - \\
\hline \multirow{19}{*}{ Near KottiyoorTemple } & Rhyachophilidae & Himalopsyche sps & - & - & 1 & A & 1 & A \\
\hline & \multirow{5}{*}{ Hydropsychidae } & Potamya sps & 5 & B & 1 & A & 5 & B \\
\hline & & Cheumatopsyche sps & - & - & - & - & 1 & A \\
\hline & & Polymorphan sps & - & - & - & - & - & - \\
\hline & & Macrostemum sps & - & - & 1 & A & - & - \\
\hline & & Hydropsychae sps & 2 & $\mathrm{~B}$ & - & - & 2 & B \\
\hline & Chironomidae & Chironomus larvae & 2 & $\mathrm{~B}$ & - & - & 8 & B \\
\hline & \multirow{2}{*}{ Leptophlebiidae } & Habrophlebiodes sps & - & - & - & - & - & - \\
\hline & & Megaglena sps & 1 & A & 3 & B & 1 & A \\
\hline & Ephemerellidae & Ephemerella sps & - & - & - & - & 1 & A \\
\hline & Baetidae & Baetis sps & 1 & A & - & - & 1 & A \\
\hline & Heptageniidae & Epeorus sps & - & - & - & - & - & - \\
\hline & \multirow{2}{*}{ Gomphidae } & Paragomphus sps & - & - & - & - & - & - \\
\hline & & Leptogomphus sps & - & - & - & - & 1 & A \\
\hline & Dryopidae & Dryops larvae & - & - & - & - & 1 & A \\
\hline & Psephenidae & Psephenoidinae sps & - & - & - & - & 1 & A \\
\hline & Thiaridae & Melanoides sps & 1 & A & 1 & A & 5 & B \\
\hline & Lymnaeidae & Lymnaea sps & 2 & B & 1 & A & 0 & \\
\hline & Belastomatidae & Sphaerodema sps & - & - & - & - & 4 & B \\
\hline \multirow{10}{*}{$\begin{array}{c}\text { Munambukadavu } \\
\text { Bridge }\end{array}$} & Rhyachophilidae & Himalopsyche sps & - & - & - & - & 1 & A \\
\hline & \multirow{5}{*}{ Hydropsychidae } & Potamya sps & 4 & B & - & - & - & - \\
\hline & & Cheumatopsyche sps & 1 & A & 1 & A & 1 & A \\
\hline & & Polymorphan sps & 2 & B & 1 & A & 2 & B \\
\hline & & Macrostemum sps & 4 & B & 2 & B & 4 & B \\
\hline & & Hydropsychae sps & 6 & B & 1 & A & 6 & B \\
\hline & Chironomidae & Chironomus larvae & 4 & B & 1 & A & 4 & B \\
\hline & \multirow{2}{*}{ Leptophlebiidae } & Habrophlebiodes sps & 2 & B & 1 & A & 2 & B \\
\hline & & Megaglena sps & 1 & A & 1 & A & 1 & A \\
\hline & Ephemerellidae & Ephemerella sps & - & - & 1 & A & - & - \\
\hline
\end{tabular}


Table 5. contd....

\begin{tabular}{|c|c|c|c|c|c|c|c|c|}
\hline \multirow{2}{*}{ Stations } & \multirow{2}{*}{ Family } & \multirow{2}{*}{ Genus Name } & \multicolumn{2}{|c|}{ Pre } & \multicolumn{2}{|c|}{ Mon } & \multicolumn{2}{|c|}{ Post } \\
\hline & & & $\mathbf{N}$ & $\mathbf{A}$ & $\mathbf{N}$ & $\mathbf{A}$ & $\mathbf{N}$ & $\mathbf{A}$ \\
\hline & Baetidae & Baetis sps & 4 & B & 5 & $\mathrm{~B}$ & 5 & B \\
\hline & Heptageniidae & Epeorus sps & - & - & - & - & - & - \\
\hline & & Paragomphus sps & - & - & - & - & - & - \\
\hline & & Leptogomphus sps & 1 & A & 1 & A & 1 & A \\
\hline & Dryopidae & Dryops larvae & 1 & $\mathrm{~A}$ & 1 & A & 1 & A \\
\hline & Psephenidae & Psephenoidinae sps & - & - & 1 & A & - & - \\
\hline & Thiaridae & Melanoides sps & 4 & $\mathrm{~B}$ & 1 & $\mathrm{~A}$ & 7 & $\mathrm{~B}$ \\
\hline & Lymnaeidae & Lymnaea sps & 3 & $\mathrm{~B}$ & - & - & 4 & B \\
\hline & Belastomatidae & Sphaerodema sps & - & - & - & - & - & - \\
\hline \multirow{19}{*}{ Valapattanam Bridge } & Rhyachophilidae & Himalopsyche sps & 1 & A & - & - & 1 & A \\
\hline & \multirow{5}{*}{ Hydropsychidae } & Potamya sps & 9 & $\mathrm{~B}$ & - & - & 5 & $\mathrm{~B}$ \\
\hline & & Cheumatopsyche sps & 5 & $\mathrm{~B}$ & - & - & - & - \\
\hline & & Polymorphan sps & 3 & $\mathrm{~B}$ & - & - & - & - \\
\hline & & Macrostemum sps & 2 & $\mathrm{~B}$ & - & - & 1 & A \\
\hline & & Hydropsychae sps & 5 & $\mathrm{~B}$ & - & - & 1 & A \\
\hline & Chironomidae & Chironomus larvae & 2 & $\mathrm{~B}$ & 1 & A & 5 & B \\
\hline & \multirow{2}{*}{ Leptophlebiidae } & Habrophlebiodes sps & 2 & $\mathrm{~B}$ & 1 & A & 2 & B \\
\hline & & Megaglena sps & 9 & B & - & - & 4 & B \\
\hline & Ephemerellidae & Ephemerella sps & - & - & - & - & 2 & B \\
\hline & Baetidae & Baetis sps & 5 & $\mathrm{~B}$ & 5 & $\mathrm{~B}$ & 5 & B \\
\hline & Heptageniidae & Epeorus sps & - & - & 1 & $\mathrm{~A}$ & - & - \\
\hline & \multirow{2}{*}{ Gomphidae } & Paragomphus sps & 1 & $\mathrm{~A}$ & 1 & $\mathrm{~A}$ & 1 & A \\
\hline & & Leptogomphus sps & 1 & A & - & - & - & - \\
\hline & Dryopidae & Dryops larvae & 4 & $\mathrm{~B}$ & 1 & A & - & - \\
\hline & Psephenidae & Psephenoidinae sps & 1 & A & - & - & 1 & A \\
\hline & Thiaridae & Melanoides sps & 3 & B & 1 & A & 1 & A \\
\hline & Lymnaeidae & Lymnaea sps & 2 & $\mathrm{~B}$ & 1 & A & 4 & B \\
\hline & Belastomatidae & Sphaerodema sps & 1 & A & - & - & 1 & A \\
\hline
\end{tabular}

Abundance of benthic macro invertebrates

N- No:of organisms A- Abundance Pre-Pre monsoon Mon-Monsoon Post-Post monsoon

and diversity scores of these stations were positively correlated $(+0.71,+0.96 \&+0.90$ respectively).

\section{DISCUSSION}

The water quality of Valapattanam River appears to have deteriorated as a result of various anthropogenic and local land uses. Since the River originates from the Western Ghats (Western Ghats or the Sahyadri constitute a mountain range along the western side of India. It is a UNESCO World Heritage Site and is one of the eight "hottest hotspots" of biological diversity in the world) considered to be a protected region under the Reserve Forest Area, the quality of upstream water implies to be excellent in nature. The upstream station 
Aralam was found to be slightly polluted in both monsoon and post monsoon season. Vallithode was also not clean. This sector can be influenced by the discharge of domestic effluent and by community bathing. Interestingly during premonsoon, Aralam was clean while Vallithode was found to be polluted and these were respectively the maximum and minimum saprobic scores obtained in the study. This indicates that Aralam is comparatively less influenced by human activities when compared to Vallithode. Abundance of benthic macro invertebrates is depicted in Table 5. As the station near Kottiyoor temple, Chironomus sps were abundant during pre and post monsoon seasons indicating the low oxygen conditions at the bottom of the river as a result of high degree of organic degradation. This species was observed in pre and post-monsoon surveys only. It is reported that the abundance of this pollution tolerant species of benthic fauna in Neyyar River in both these seasons is a clear indication of organic contamination and the enrichment of organic matter in the river bed [17]. This stream near temple being a pilgrim spot attracts pilgrims during the monsoon season resulting in pollution of streams with organic waste. The species was recorded only when the stream was moderately polluted. Due to the increase in flow of the stream during monsoon, pollution level seems to decrease slightly and water quality improved and impact of monsoon pilgrimage became evident only during post monsoon where water again became moderately polluted.

Downstream stations such as Munambukadavu Bridge and Valapattanam Bridge also reported similar trend.ie moderate pollution during pre and post monsoon seasons and slight improvement during monsoon. The tolerant species of Tricoptera are usually associated with highly polluted water. So the presence of Macrostemum sps at Munambukadavu Bridge and Valapattanam Bridge indicates the pollution of water. Caddis fly occur in most type of fresh water habitats: spring streams and seepage areas, rivers, lakes, marshes and temporary pools [18]. The Tricoptera and Diptera have the capability to adapt to varied aquatic habitats due to their extra ordinary structural organization [19-21]. The degraded quality of water affects macro invertebrates by eliminating many of them and those remain will be abundant due to either decreased competition or increased tolerance [22]. The highest diversity of benthic macro invertebrates were noticed in Valappatanam bridge during pre monsoon season.

All the stations except Aralam showed an improvement in water quality during monsoon.ie pollution level decreased from moderate to slight. This may be due to the flood occurred as a result of series of landslides in the upstream areas of the river during the period of study. More pollution sensitive genera were observed during the monsoon season, this might be due to the high flow rate and the dilution. The impact of landslide was observed more at Aralam, an upstream station. Population of some of the common benthic organisms decreased. This might be due to the washing away of benthic forms or logging in and clumping of organic substances reached in the river from uphill areas during landslide occurred in Aralam.

Aralam and Vallithode were the stations which showed considerable change in water quality during the complete period of study. At Aralam saprobic score was reduced and diversity score was increased from premonsoon to monsoon indicating an increase in number and diversity of pollutiontolerant organisms. At Vallithode reverse phenomena happened i.e. number of pollution sensitive organisms increased.

One of the major environmental problems faced by the rivers of Kerala is due to the disposal of untreated municipal sewage. This may result in the organic pollution of the rivers [17]. Biological water Quality assessment of Karamana River by using benthic macro invertebrates, Southern Kerala, India found that the water quality showed a sudden decline as the river heaves towards the discharge site [23]. The upstream stations Kottiyoor showed similar trend as downstream stations regarding the biological quality. This might be because of high influence of rain and other climatic factors in northern part of Kerala during the period of study.

\section{CONCLUSION}

Various anthropogenic activities are showing its impacts on the water quality of Valapattanam River. Upstream stations Aralam and Vallithode showed fluctuations in macroinvertebrate diversity and biological water quality. Kottiyur and downstream stations Munambukadavu and Valapattanam Bridge showed moderate pollution and diminishing the abundance of sensitive organisms.

\section{CONFLICT OF INTEREST}

The authors confirm that this article content has no conflicts of interest.

\section{ACKNOWLEDGEMENTS}

The authors are thankful to Kerala State Council for Science, Technology and Environment, Trivandrum, Kerala, India for the financial support.

\section{REFERENCES}

[1] Ramakrishnan N. Bio-Monitoring Approaches For Water Quality Assessment in Two Waterbodies at Tiruvannamalai, Tamil Nadu India In: Bunch MJ, Suresh VM, Kumaran TV, Eds. Proceedings of the Third International Conference on Environment and Health, Chennai, India. Department of Geography, University of Madras and Faculty of Environmental Studies, York University 2003; pp. 374-85.

[2] Paerl HW, Valdes-Weaver LM, Joyner AR, Winkelmann V. Phytoplankton indicators of ecological change in the Eutrophying Pamlico sound system, North Carolina. Ecol Appl (Supplement by the Ecological Society of America) 2007; 17(5): S88-S101.

[3] Sultana R, Kala DS. Water body quality analysis by Benthic Macro invertebrates. Int J Pharm BioSci 2012; 2(1): 269-79.

[4] Sharma MP, Sharma S, Goel V, Sharma P, Kumar A. Water quality Assessment of Behta River using benthic macroinvertebrates. Life Sci J 2006; 3(4): 134-6.

[5] Sharma C, Rawat JS. Montoring of aquatic macroinvertebrates as bioindicator for assessing the health of wetlands: A case study in the central Himalayas India. Ecol Indicat 2009; 9: 118-28.

[6] Thorne, R.S.J., Williams, W.P., The response of benthic macro invertebrate to pollution in developing countries: A multimetric system of bioassessment. Freshw Biol 1997; 37: 671-86

[7] Kazanci N, Dugel M. Ordination and classification of macroinvertebrates and environmental data of stream in Turkey. Water Sci Technol 2000; 47: 7-8. 
[8] EPA. Lake and reservoir bioassessment and biocriteria, technical guidancedocument. US Environmental Protection Agency, Washington, D.C. USA 1998

[9] Meyer JL, Strayer DL, Wallace JB, Eggert SL, Helfman GS, Leonard NE. The contribution of headwater streams to biodiversity in river networks. J Am Water Res Assoc 2007; 43: 86-103.

[10] Richardson JS, Danehy RJ. A synthesis of the ecology of headwater streams and their riparian zones in temperate forests. For Sci 2007; 53: 131-47.

[11] Latha C, Salom GTV. Macroinvertebrate diversity of Veli and Kadinamkulam lakes, South Kerala, India. J Environ Biol 2010; 31(4): 543-7.

[12] Report on Environmental Monitoring programme on water quality. Centre for Water Resources development and Management (CWRDM), Kerala State Council for science technology and environment 2012.

[13] CPCB. Bio-Mapping of Rivers, Parivesh, A news letter from ENVIS Centre-Central Pollution Control Board, March 1999.

[14] Edmondson WT. Ward and Whipple's Fresh Water Biology. $2^{\text {nd }}$ ed. New York: John Wily and Sons 1993.

[15] Pennak RW. Fresh water invertebrates of the United States; Protozoa to Mollusca. USA: John Wily and Sons Inc 1989.
[16] Merritt RW, Cummins KW. An introduction to the Aquatic Insects of North America. $3^{\text {rd }}$ ed. Iowa: Kendall/Hunt Publishing Company 1996; p. 862.

[17] Sreejith KP, Kumar RMP, Kumar HPS, Kokkal K. Comparison of water quality of east and west flowing River basins of Kerala employing plankton and benthic analysis. Indian J Environ Ecoplan 2008; 15(3): 463-70.

[18] Betten C. The caddis flies or Tricoptera of New York State. Bull NY State Museum 1934; 292: 1-576.

[19] Tyagi P. Occurrence of benthic macro invertebrates families encountered in river Hindan in Uttar Pradesh (India). J Zool India 2006; (9): 209-16.

[20] Needham IG, Needham PR. A guide to the study of fresh-water Biology. USA: Holdden \& Day San Francisco 1969; p. 108

[21] Tonapi GT. Fresh water animals of India: An ecological approach. New Delhi: Oxford and IBH Publishing Co 1980; p. 341.

[22] Myslinski E, Ginsburg W. Macro invertebrates as indicators of pollution. J Am Water Work Assoc 1977; 69: 538-44.

[23] Santhosh S, Mohan KC, Dhanesh NR, Akolkar P. Water quality assessment of river Karamana by using Benthic macro invertebrates, Southern Kerala, India. Ecoscan 2011; 5(3\&4): 135-40.

Received: August 17, 2013

(C) Harikumar et al.: Licensee Bentham Open.

This is an open access article licensed under the terms of the Creative Commons Attribution Non-Commercial License (http://creativecommons.org/licenses/ by-nc/3.0/) which permits unrestricted, non-commercial use, distribution and reproduction in any medium, provided the work is properly cited. 